Article

\title{
Determinants of Food Crop Diversity and Profitability in Southeastern Nigeria: A Multivariate Tobit Approach
}

\author{
Sanzidur Rahman * and Chidiebere Daniel Chima \\ School of Geography, Earth and Environmental Sciences, University of Plymouth, Drake Circus, Plymouth, \\ PL4 8AA, UK; chimachidiebere5@gmail.com \\ * Correspondence: srahman@plymouth.ac.uk; Tel.: +44-1752-585-911; Fax: +44-1752-584-710 \\ Academic Editor: Les Copeland \\ Received: 27 November 2015; Accepted: 23 March 2016; Published: 1 April 2016
}

\begin{abstract}
The present study jointly determines the factors influencing decisions to diversify into multiple food crops (i.e., rice, yam and cassava) vis-à-vis profitability of 400 farmers from Ebonyi and Anambra states of Southeastern Nigeria using a multivariate Tobit model. Model diagnostic reveals that the decisions to diversify into multiple crops and profits generated therefrom are significantly correlated, thereby justifying use of a multivariate approach. Results reveal that $68 \%$ of the farmers grew at least two food crops and profitability is highest for only rice producers followed by joint rice and yam producers, which are mainly for sale. Farm size is the most dominant determinant of crop diversity vis-à-vis profitability. A rise in the relative price of plowing significantly reduces profitability of yam and rice. High yield is the main motive for growing yam and cassava whereas ready market is for rice. Other determinants with varying level of influences are proximity to market and/or extension office, extension contact, training, agricultural credit, subsistence pressure and location. Policy recommendations include investments in market infrastructure and credit services, land and/or tenurial reform and input price stabilization to promote food crop diversity vis-à-vis profitability in Southeastern Nigeria.
\end{abstract}

Keywords: Socio-economic determinants; food crop diversity; profitability; multivariate Tobit model; Southeastern Nigeria

\section{Introduction}

A major criticism of the widespread diffusion of the cereal based Green Revolution (GR) technology in Asia and Latin America is its adverse effect on the loss of biodiversity and dominance of cereal monoculture. Although GR technology diffusion was attempted in Africa, the success and extent of adoption was limited and the continent is still characterized by diversified agriculture and semi-subsistence farming.

Nigeria, the largest economy in Africa with rich reserves of crude oil resources, is still dependent on the agricultural sector for the supply of raw materials, food, and foreign exchange and employs over $70 \%$ of the labor force [1]. The sector is also characterized by small-scale semi-subsistence farming system comprising more than 70 million farmers/rural citizens [1]. Although the agricultural sector is believed to have high potential, it is characterized by low level of productivity and modern technology adoption $[2,3]$.

Conventionally, cassava and yam were the main staple food crops in Nigeria with wide range of industrial and commercial uses as well. The country is one of the leading producers of cassava and yam in the world, supplying more than $68 \%$ of global yam production and providing the majority of the calorie requirements of its vast population base from these two staples [4-7]. However, over 
the past two decades, rice is also gaining momentum as a major staple food crop in Nigeria, growing at an annual rate of $14 \%$ from 1990 by mainly substituting other coarse grains, roots and tubers for consumption [8]. Awerije and Rahman [9] noted a number of constraints, e.g., low level of productivity and efficiency, lack of processing and poor marketing infrastructure, are hindering the cassava sector to realize its strong potential to support agricultural growth in Nigeria. Similarly, the potential of yam is also affected due to constraints in unavailability and affordability of high quality seed yams, on-farm postharvest losses, low soil fertility, and unexploited potential of yam markets by smallholder farmers [7]. There is substantial yield gap of these major staples as compared to their potential. For example, the current yield of rice, cassava and yam is only 1.9, 12.3 and $12.3 \mathrm{mt} / \mathrm{ha}$, whereas the potential yields could be 7.0, 28.04 and $18.0 \mathrm{mt} / \mathrm{ha}$, respectively [10]. In addition, for the majority of these semi-subsistence farmers, agriculture is seen as a way of life and not a business aimed at maximizing production, yield and/or profits [11].

Manyong et al. [12] noted that the most fundamental constraint to agricultural growth in Nigeria is peasant production system, poor response to technology adoption, land fragmentation and crop failure which increases production risk and perhaps explains why small and poor farmers have embraced crop diversification or producing multiple crops adapted to specific agro-ecological zones [13]. Crop diversification as a farming strategy believed to have a number of advantages, e.g., ability to reduce and spread risk, improve income and employment opportunity, ability to reduce disease and pest infestations and improve soil fertility in some cases [14]. Bamji [15] noted that diversification within food crops and/or between crops and livestock improves nutrition security, particularly for the poor and marginal farmers.

The literature on the impact of crop diversification is quite mixed. For example, Guvele [16] noted that crop diversification reduces income variability in Sudan, whereas van den Berg et al. [17] noted that it sustains income level for farmers in China. Kar et al. [18] and Rahman [19] noted that crop diversification increases agricultural production in India and Bangladesh, respectively. Llewelyn and Williams [20] and Haji [21] noted that crop diversification decreases farmers' production efficiency in Indonesia and Ethiopia, respectively while Coelli and Fleming [22] and Rahman [19] reported that crop diversification actually improves farmers' production efficiency in Papua New Guinea and Bangladesh, respectively. The implication is that the conclusions on the effect of crop diversification vary substantially from region to region, and therefore requires being addressed on a case-by-case basis.

Since crop diversification is being practiced by the small and poor farmers in Nigeria on the one hand [13,23], and given such poor productivity performance of major staple food crops on the other hand, despite having strong potential to support agricultural growth, it is important to: (a) examine the level and extent of food crop diversity at the farm level; and (b) identify the factors influencing food crop diversity vis-à-vis profitability at the farm level. This is because crop diversification is believed to have a number of advantages, such as, reducing variability in production, yield and/or income as well as improving production efficiency and economies of scope $[16,17,19]$.

Farmers generally produce multiple crops in order to meet their consumption and various other needs depending on their socio-economic circumstances and motivation. Literature abounds with examination of factors influencing mainly adoption of modern technology in crop production at the farm level usually focusing on single crop only [24,25], although in reality farmers produce multiple crops [26-28]. In this study, we aim at identifying farmers' decision to diversify into multiple food crop production vis-à-vis profits generated therefrom. We focus on profits generated from making crop choices because unless food is produced both for own consumption as well as for the market, the sector is unlikely to contribute significantly towards the growth of Nigerian agriculture. Farms are also businesses where decisions are made and implemented by the farmer alone under relatively more external pressures than any other businesses (Groenwald, 1987 and Errington, 1991 cited in [29]. Therefore, in order to realistically identify the host of factors influencing such a complex decision-making process, i.e., production of multiple food crops vis-à-vis profits generated therefrom, we utilize a multiple equation Tobit model which is capable of jointly estimating all the relevant 
parameters of the model and also provides evidence of jointness in the decision-making process. We depart from the conventional approach to analyze factors influencing crop diversification by specifying a composite crop diversification index, such as Herfindahl index [26,27] as a function of a set of explanatory variables composed of price and non-price variables by utilizing a regression model because we would like to simultaneously identify the nature of the combination of various food crops that the individual farmer chooses to produce and the factors influencing such decision-making process. The conventional approach using a single composite index of crop diversification will only provide information on the determinants of overall crop diversity but will not be able to demonstrate the nature of combination and whether the decisions to produce multiple crops are related or not. Also, since not all of the farmers are expected to produce all crops, but to produce any combination of the three food crops under investigation at any one time, which implies zero observations for certain crops by individual farmers, the appropriate modeling framework is the use of a truncated regression model. In our case, we apply a multiple equation Tobit model instead of a single equation Tobit model because the latter can accommodate decision to choose only a single crop at a time. This is the main contribution of our research to the literature on crop diversification in the sense that we aim to provide the evidence of whether the decision to produce multiple crops is related (i.e., which crops are combined and in what way) and whether the same set of factors influence decision to choose each crop or they differ across crops. We do so by using farm-level cross-sectional data of 400 farmers from Ebonyi and Anambra states of Southeastern Nigeria collected in 2012. This is because a thorough understanding of farmers' decision-making process is of genuine interest to the policy makers and academics [29].

The paper is structured as follows. Section 2 presents the analytical framework, study area and the data. Section 3 presents the results. Section 4 concludes and draws policy implications.

\section{Methodology}

\subsection{Modelling Factors Influencing Crop Diversity: Multivariate Tobit Model}

Studies abound which have explored determinants of modern technology adoption and/or crop choices and/or crop diversity largely applying univariate probit, Tobit or logit regressions of a single crop on variables representing socio-economic circumstances of farmers $[24,25,27,30]$. The implicit theoretical underpinning of all such modeling exercise is the assumption of utility maximization by rational farmers, and forms the theoretical basis of our study as well.

We postulate that the farmers follow sequential decisions; first "whether to choose to grow a particular food crop or not"; and second, conditional on choice, what is the level or intensity of such choice? In such a case, a censored regression model is required. A Tobit model is the most suitable because it uses all observations, both those at the limit, usually zero (e.g., who did not choose the particular crop), and those above the limit (e.g., who chose the particular crop) to estimate a regression line as opposed to other techniques that use only observations that are above the limit value [31]. The procedure also captures latent level of intensity of potential farmers who decide not to choose a particular crop. Another feature of the Tobit model is that it is a truncated regression model where the values above the threshold can be continuous. For example, in our case the threshold is 0 (i.e., lower limit) and all values above that limit is continuous, i.e., the actual level of profit derived from growing the chosen crop with no upper limit set. Therefore, cases where zero observations are a norm (e.g., when a farmer do not chose a certain crop), use of truncated regression model is more appropriate than Ordinary Least Square model.

Let the outcome function for choosing a particular food crop (measured as profitability, i.e., profit per ha) derived from the chosen crop) be given by:

$$
Y_{i}^{*}=\gamma^{\prime} X_{i}+\mu_{i}
$$


where $X_{i}$ is the vector of regressors, $\gamma$ is the vector of parameters to be estimated, and $\mu_{i}$ is the error term. For households choosing yam, $Y_{i}^{*}$ equals the actual level of returns $\left(Y_{i}\right)$. For those who did not choose yam, $Y_{i}^{*}$ is an index reflecting potential return such that:

$$
\begin{array}{rlr}
Y_{i}=Y_{i}^{*} & \text { if } \gamma^{\prime} X_{i}+\mu_{i}>0 \\
=0 & \text { if } \gamma^{\prime} X_{i}+\mu_{i}<0
\end{array}
$$

The advantage of the Tobit model as in Equation (2) is that it captures the decision to choose as well as the resulting outcome, whereas a probit model will provide information on the decision to choose only. Since we see that a substantial proportion of farmers grew either a combination of two or all three food crops at the same time (Table 1), we postulate a multivariate Tobit model in order to capture this joint outcome:

$$
\begin{aligned}
& Y_{1 i}^{*}=\gamma^{\prime} X_{1 i}+\mu_{1 i} \\
& Y_{1 i}=\operatorname{Maximum}\left(Y_{1 i}^{*}, 0\right)(\text { the usual Tobit specification as in } 2) . \\
& Y_{2 i}^{*}=\gamma^{\prime} X_{2 i}+\mu_{2 i} \\
& Y_{2 i}=\operatorname{Maximum}\left(Y_{2 i}^{*}, 0\right)(\text { the usual Tobit specification as in } 2) . \\
& Y_{3 i}^{*}=\gamma^{\prime} X_{3 i}+\mu_{3 i} \\
& Y_{3 i}=\operatorname{Maximum}\left(Y_{3 i}^{*}, 0\right)(\text { the usual Tobit specification as in } 2) . \\
& \mu_{i i}, \mu_{2 i}, \mu_{3 i} \approx N\left[0,0,0, \sigma_{1}^{2}, \sigma_{2}^{2}, \sigma_{3}^{3}, \rho_{12}, \rho_{13}, \rho_{23}\right]
\end{aligned}
$$

where $Y_{1 i}^{*}$ denotes return of the $i$ th farmer who grew yam; $Y_{2 i}^{*}$ denotes return of the $i$ th farmer who grew cassava; $Y_{3 i}^{*}$ denotes return of the $i$ th farmer grew rice; $\rho_{12}$ is the correlation between the error terms $\mu_{1 i}$ and $\mu_{2 i} ; \rho_{13}$ is the correlation between the error terms $\mu_{1 i}$ and $\mu_{3 i}$; and $\rho_{23}$ is the correlation between the error terms $\mu_{2 i}$ and $\mu_{3 i}$. The distributions are independent if and only if $\rho_{12}=\rho_{13}=\rho_{23}=0$.

This enables us to accommodate farmer's decision to choose a single or a combination of crops at the same time. The other advantage of this multivariate approach, as opposed to the univariate approach (i.e., single equation Tobit/probit/logit models), is that it is more efficient because it not only nests individual univariate models but also enables us to demonstrate jointness of the decision-making process by providing an estimate of the correlation between the error terms of the individual univariate models. Only a few studies utilized such improved multivariate models. For example, Lansink et al. [32] and Teklewold et al. [33] used multivariate probit models for their research. Though their approach takes care of the potential correlation of disturbances arising from interrelationships of decisions of different choices, the impact of factors on the intensity of participation rates in different choices cannot be measured. Rahman and Akter [34] used multivariate Tobit model to identify determinants of three livelihood options of Bangladeshi rural households. We adopt this multivariate Tobit model in our study as it overcomes the limitation of the multivariate probit model and measures the impact of factors on the intensity of participation rates (i.e., profitability in our case) from making different crop production choices.

The model is estimated with a program code developed by Barslund [35]. The procedure involves simulation using Halton draws to generate random numbers for evaluation of the multi-dimensional Normal integrals in the likelihood function. For each observation, a likelihood contribution is calculated for each replication. The simulated likelihood contribution is the average of the values derived from all replications. The simulated likelihood function for the sample as a whole is then maximized using a standard Maximum Likelihood procedure [34].

\subsection{Study Area and the Data}

A multi-stage sampling procedure was utilized for sample selection and data collection. First, Ebonyi and Anambra states of Southeastern Nigeria were purposively chosen. Ebonyi state is newly created in 1996 and 80\% of its land rich arable land, although 90\% of its farmers are small holders and it is a predominantly rural area [36]. On the other hand, Anambra state is an older state with 
$70 \%$ of its area suitable for agricultural production and relatively urbanized in nature [37]. Three local government areas (LGAs) from each state were selected randomly based on the cell structure developed by the Agricultural Development Program, the major extension organization of the government. Next, 10 communities/villages from each LGA were chosen randomly. Next, farmers were chosen from these communities using a simple random sampling procedure. The total number of farm households in each village formed the sample frame. Then, the sample size (n) of household units in the study area is determined by applying the following formula [38]:

$$
n=\frac{N z^{2} p(1-p)}{N d^{2}+z^{2} p(1-p)}
$$

where $n=$ sample size; $N=$ total number of farm households; $z=$ confidence level (at $95 \%$ level $z=1.96) ; p=$ estimated population proportion ( 0.5 , this maximizes the sample size); and $d=$ error limit of $5 \%(0.05)$.

Application of the sampling formula presented in Equation (6) yielded a total required sample of 450 . However, a total of 600 questionnaires were distributed (300 in each state with 30 in each community). Although 290 questionnaires from Ebonyi and 190 from Anambra states were returned, complete information was available in only 249 and 141 questionnaires from these states, respectively. Therefore, the final sample size stands at 400 households. Details on input and output data on three major food crops (i.e., cassava, yam and rice) were recorded in addition to key demographic and socio-economic information from each of the farm households. The co-author and two trained research assistants who are agricultural graduates were used for collecting primary data.

\subsection{The Empirical Model}

A multivariate Tobit model is developed to empirically investigate the socio-economic factors underlying the decision to grow multiple crops. The dependent variables are whether the farmer produced yam, cassava or rice. For each case of the chosen crop, the variable takes the value of profitability (i.e., profit per ha) derived from making such choice and 0 otherwise. Therefore, a total of three Tobit equations are postulated which provides a total of seven possible combination of choices (Table 1).

The following broad categories of factors were selected to explain multiple food crop choice decisions vis-à-vis profitability. These are: (a) prices of outputs (i.e., cassava, yam, and rice) and inputs (i.e., inorganic fertilizers, labor, and plowing); (b) socio-economic factors, which include farm operation size, family size, farming experience, education of the farmer, tenurial status, main occupation as farmer, gender of the farmer, and subsistence pressure; (c) institutions and services, which include the distance to extension office, distance to market, extension contact, training received and amount of agricultural credit received; (d) modern technology adoption defined as dummy variable for inorganic fertilizer use; (e) motivation for choice, which include high yield motive and ready market motive; and (f) locational factor with dummy for farmers of Ebonyi state. The choice of these explanatory variables is based on the literature with similar justification [24-27]. Farmers were asked about the motivation for making their crop choice decision and to rank each of the motives ((e.g., high yield, ready market, etc.) on a five-point Likert scale (i.e., 1 for least important motive and 5 for most important motive). This is because farmers' decision-making process is also influenced by attitudes, objectives, behaviors and personality traits in addition to socio-economic factors $[29,39,40]$. Table 2 presents definitions and summary statistics of the variables used in the multivariate Tobit model.

\section{Results and Discussion}

\subsection{Extent of Major Food Crop Diversity at the Farm Level}

Cassava and yam are encouraged in Africa for sustainable food production because of their vital importance as a cheap source of nutrition and food security, widespread adaptability to agro-ecological 
conditions, longer crop cycle ensuring annual cycle of food availability and diverse maturity period [41]. As mentioned earlier, although cassava and yam are the traditional food crops in Nigeria grown for centuries, rice is a relatively new crop that is gaining momentum from the 1990s. In terms of sustainable production practices regarding production of major food crops, it seems that the use of traditional technologies still dominates in Nigerian farming. For example, Rahman and Chima [42] noted that the level of modern technology adoption in food crops (i.e., cassava, yam and rice) is very low in Nigeria as only $35 \%, 18 \%$ and $12 \%$ of the sampled farmers actually adopted High Yielding Varieties (HYVs) of cassava, yam and rice, respectively. Similarly, the use of inorganic fertilizer was very low as only $30 \%$ of the total farmers applied fertilizers in any one crop [42]. Although supplementary irrigation is expected to be used in rice production at least, none of the farmers seem to have applied irrigation. However, use of liquid fertilizer was observed for very few farmers (about 3.5\% of the total farmers) mainly applying in rice crop, which is a relatively new phenomenon. Use of pesticides was also low as $50.3 \%, 33.3 \%$ and $26.2 \%$ of the sampled farmers applied pesticides in rice, yam and cassava, respectively. Sanginga [41] also noted limited use of fertilizers, irrigation and herbicides in the production of root crops in Africa.

Table 1 presents the extent of diversity in food crop production amongst the sampled farmers. It is clear form Table 1 that farmers grow multiple crops. A total of seven combinations of food crop production were observed. Only $18 \%$ of the farmers produced a single crop of cassava with lowest average farm size of only 0.53 ha, whereas "only rice" or "only yam" produces are a third of that with relatively higher farm sizes. On the other hand, a substantial $41 \%$ of the farmers grew a combination of yam and cassava with an average operation size of 0.99 ha followed by $24.8 \%$ of farmers growing all three major food crops with highest average operation size of 2.54 ha. The implication is that small farms with their tiny farm size tend to grow at least two crops, whereas large farms can afford to grow all three crops due to command over a larger cultivated area.

However, when profitability was examined, the picture is rather different. Overall, profitability is 338.4 thousand Naira per ha. But profitability is highest for "only rice" production estimated at 740.5 thousand Naira per ha and lowest for "only cassava" production estimated at 157.6 thousand Naira per ha. No wonder why cassava farmers in Nigeria are poor and struggle to raise subsistence only. The second highest level of profitability is for farmers jointly producing rice and yam, estimated at 505.3 thousand Naira per ha, both of which are largely sold in the market (Table 1).

Table 1. Extent of food crop diversity and profitability amongst the sampled farmers.

\begin{tabular}{|c|c|c|c|c|}
\hline Producer Categories & $\begin{array}{l}\text { Percent of Total } \\
\text { Farmers }(\%)\end{array}$ & $\begin{array}{l}\text { Farm Operation } \\
\text { Size (ha) }\end{array}$ & $\begin{array}{l}\text { Gross Return } \\
\text { (Naira per ha) }\end{array}$ & $\begin{array}{l}\text { Profitability } \\
\text { (Naira pe ha) }\end{array}$ \\
\hline $\begin{array}{l}\text { Only rice producer }(\text { rice }=1 \\
\text { yam }=0 ; \text { cassava }=0)\end{array}$ & 6.25 & 0.79 & 1075340.0 & 740536.2 \\
\hline $\begin{array}{c}\text { Only yam producer }(\text { rice }=0 ; \\
\text { yam }=1 ; \text { cassava }=0)\end{array}$ & 5.25 & 0.68 & 558476.2 & 383312.4 \\
\hline $\begin{array}{c}\text { Only cassava producer }(\text { rice }=0 ; \\
\text { yam }=0 ; \text { cassava }=1)\end{array}$ & 18.00 & 0.53 & 249622.1 & 157553.0 \\
\hline $\begin{array}{l}\text { Rice and yam producer }(\text { rice }=1 ; \\
\qquad y a m=1 ; \text { cassava }=0)\end{array}$ & 2.50 & 1.20 & 789966.0 & 505291.0 \\
\hline $\begin{array}{l}\text { Rice and cassava producer } \\
(\text { rice }=1 ; \text { yam }=0 ; \text { cassava }=1)\end{array}$ & 2.25 & 1.24 & 671714.6 & 419673.0 \\
\hline $\begin{array}{l}\text { Yam and cassava producer } \\
(\text { rice }=0 ; \text { yam }=1 ; \text { cassava }=1)\end{array}$ & 41.00 & 0.99 & 405167.1 & 261692.2 \\
\hline $\begin{array}{l}\text { Rice, yam and cassava producer } \\
(\text { rice }=1 ; \text { yam }=1 ; \text { cassava }=1)\end{array}$ & 24.75 & 2.54 & 610350.8 & 461831.5 \\
\hline Overall & 100.00 & 1.27 & 493728.8 & 338439.0 \\
\hline $\begin{array}{l}\text { Number of observations } \\
\text { (farm households) }\end{array}$ & 400 & & & \\
\hline
\end{tabular}




\subsection{Factors Affecting Food Crop Diversity and Profitability: A Multivariate Tobit Analysis}

The summary statistics of the variables used in the econometric model is presented in Table 2. It is clear from Table 2 that the profitability per ha is highest for rice estimated at Naira 287,825.10 followed by yam at Naira 27,4158.50. On the other hand, profitability of cassava is approximately half of the other two crops, estimated at only Naira 134,430.70. Among the prices, rice price is highest followed by yam and then cassava, which may be largely responsible for higher profits for rice and yam. Among the socio-economic characteristics we see that farming experience is about 20 years and average education is about mid-secondary level with 7.84 years of completed schooling. Among the institutional facilities, the average distance of agricultural extension office is $3.64 \mathrm{~km}$ and the average distance to market is $6.71 \mathrm{~km}$. Only $15 \%$ of the farmers contact with extension services over the past one year and only $10 \%$ of the farmers had any training. The average level of agricultural credit is low, estimated at Naira 5885.40 with very high standard deviation.

Table 2. Definition, measurement and summary statistics of the variables used in the econometric model.

\begin{tabular}{|c|c|c|c|}
\hline Variables & Measurement & Mean & Standard Deviation \\
\hline $\begin{array}{l}\text { Dependent variable } \\
\text { Yam profitability } \\
\text { Cassava profitability } \\
\text { Rice profitability }\end{array}$ & $\begin{array}{l}\text { Naira per ha } \\
\text { Naira per ha } \\
\text { Naira per ha }\end{array}$ & $\begin{array}{l}274,158.50 \\
134,430.70 \\
287,825.10\end{array}$ & $\begin{array}{l}195,441.00 \\
71,253.85 \\
39,9584.80\end{array}$ \\
\hline $\begin{array}{c}\text { Prices }^{\text {a }} \\
\text { Yam price } \\
\text { Cassava price } \\
\text { Rice price } \\
\text { Fertilizer price (yam producers) } \\
\text { Fertilizer price (cassava producers) } \\
\text { Fertilizer price (rice producers) } \\
\text { Labor wage (yam producers) } \\
\text { Labor wage (cassava producers) } \\
\text { Labor wage (rice producers) } \\
\text { Plowing price (yam producers) } \\
\text { Plowing price (cassava producers) } \\
\text { Plowing price (rice producers) }\end{array}$ & $\begin{array}{c}\text { Naira per } \mathrm{kg} \\
\text { Naira per } \mathrm{kg} \\
\text { Naira per } \mathrm{kg} \\
\text { Naira per } \mathrm{kg} \\
\text { Naira per } \mathrm{kg} \\
\text { Naira per } \mathrm{kg} \\
\text { Naira per person day } \\
\text { Naira per person day } \\
\text { Naira per person day } \\
\text { Naira per ha } \\
\text { Naira per ha } \\
\text { Naira per ha }\end{array}$ & $\begin{array}{c}37.22 \\
7.88 \\
51.47 \\
103.37 \\
106.29 \\
100.24 \\
718.30 \\
622.93 \\
763.16 \\
13,288.52 \\
11,189.72 \\
14,409.45\end{array}$ & $\begin{array}{c}22.18 \\
7.22 \\
6.07 \\
4.51 \\
3.96 \\
4.47 \\
192.17 \\
153.57 \\
313.95 \\
5436.33 \\
6543.66 \\
5017.59\end{array}$ \\
\hline $\begin{array}{l}\text { Institutions and services } \\
\text { Distance to extension office } \\
\text { Distance to market } \\
\text { Extension contact } \\
\text { Training received } \\
\text { Agricultural credit }\end{array}$ & $\begin{array}{c}\mathrm{Km} \\
\mathrm{Km} \\
\text { Number of contacts over the past one year } \\
\text { Total number of days of training received } \\
\text { Naira }\end{array}$ & $\begin{array}{l}3.64 \\
6.71 \\
0.15 \\
0.10 \\
5885.40\end{array}$ & $\begin{array}{c}3.56 \\
12.43 \\
0.56 \\
0.34 \\
29,208.13\end{array}$ \\
\hline $\begin{array}{l}\text { Modern technology } \\
\text { Fertilizer use }\end{array}$ & Dummy ( 1 if used fertilizers, 0 otherwise) & 0.47 & - \\
\hline $\begin{array}{c}\text { Location } \\
\text { Ebonyi state } \\
\text { Number of observations }\end{array}$ & Dummy ( 1 if Ebonyi state, 0 otherwise) & $\begin{array}{c}0.65 \\
400\end{array}$ & - \\
\hline
\end{tabular}

Results of the full information maximum likelihood estimation of the multivariate Tobit model are presented in Table 3. This system of three Tobit equations accommodates all seven combinations of crop choices presented in Table 1 and are estimated simultaneously as a system, not one equation at a time as conventionally done. For example, if farmer A produced cassava only but not yam or rice, his/her information appeared in the cassava equation with non-zero profit from cassava production as the dependent variable and zero profit in the other two equations. Similarly, if farmer B produced cassava 
and yam but not rice, his/her information appeared in the cassava and yam equations with non-zero profits from producing cassava and yam as the dependent variables, respectively and zero profit in the rice equation. Furthermore, if farmer $C$ produced all three crops, his/her information appeared in all three equations with non-zero profits as the dependent variables from producing all three crops, respectively. The simultaneous estimation of these three crop choice models accommodating all seven possible combinations also provide evidence of pairwise jointness in decision making. The key hypothesis of "correlation of the disturbance term between the pair of equations is zero $\left\{i . e ., \rho_{j k}=0\right\}$ " is strongly rejected at the $1 \%$ level of significance for two pairs, implying that the use of a multivariate Tobit model to determine farmers' decision underlying choice of food crop production is correctly justified. The Likelihood Ratio test result, presented at the bottom panel of Table 3, also statistically validates that food crop choices of the farmers are strongly correlated. The positive correlation

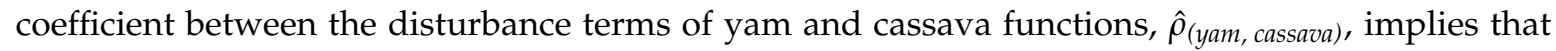
the unobservable factors that increase the probability of producing yam also increase the probability of producing cassava, which reinforces the findings presented in Table 1 that a substantial $41 \%$ of farmers produced both yam and cassava. Similarly, the negative correlation coefficient between the disturbance term of cassava and rice, $\hat{\rho}_{(\text {cassava, }}$ rice) , implies that the unobservable factors which increase the probability of producing rice reduces the probability of producing cassava, which again reinforces the findings in Table 1 that only $2.25 \%$ of the total farmers (lowest amongst the sample) actually jointly produced cassava and rice.

Table 3. Joint determination of factors influencing choice of crop diversity and profitability: a multivariate Tobit model.

\begin{tabular}{|c|c|c|c|c|c|c|}
\hline \multirow{2}{*}{ Variables } & \multirow{2}{*}{$\frac{\text { Yam }}{\text { Coefficient }}$} & \multirow[b]{2}{*}{$z$-Value } & \multicolumn{2}{|l|}{ Cassava } & \multicolumn{2}{|l|}{ Rice } \\
\hline & & & Coefficient & $z$-Value & Coefficient & $z$-Value \\
\hline Intercept & $-337,208.6000^{* * *}$ & -3.62 & 707.8483 & 0.02 & $-112,304.6000$ & -0.33 \\
\hline $\begin{array}{l}\text { Prices } \\
\text { Relative price of fertilizer } \\
\text { Relative labor wage } \\
\text { Relative price of plowing }\end{array}$ & $\begin{array}{c}-1894.7210 \\
47,195.2800^{* * *} \\
-231.2986^{* * *} \\
\end{array}$ & $\begin{array}{l}-1.32 \\
14.12 \\
-2.57 \\
\end{array}$ & $\begin{array}{c}125.7419 \\
-331.2350 \\
5.5433 \\
\end{array}$ & $\begin{array}{c}0.96 \\
-0.95 \\
0.86\end{array}$ & $\begin{array}{l}53,022.8000^{* * *} \\
6637.7470 \\
-2128.8980^{* * *} \\
\end{array}$ & $\begin{array}{c}2.94 \\
1.38 \\
-5.87 \\
\end{array}$ \\
\hline $\begin{array}{c}\text { Socio-economics characteristics } \\
\text { Farm operation size } \\
\text { Family size } \\
\text { Farming experience } \\
\text { Education } \\
\text { Tenancy } \\
\text { Main occupation as farmer } \S \\
\text { Gender } \S \\
\text { Subsistence pressure }\end{array}$ & $\begin{array}{c}29,245.1400^{* * *} \\
6224.8620 \\
-9.5469 \\
-1226.3720 \\
-13,960.8900 \\
1860.5190 \\
-14633.0100 \\
-8632.3610^{* * *} \\
\end{array}$ & $\begin{array}{c}2.50 \\
1.06 \\
-0.01 \\
-0.48 \\
-0.84 \\
0.09 \\
-0.59 \\
-3.62 \\
\end{array}$ & $\begin{array}{c}17,804.5400^{* * *} \\
2772.0100 \\
-613.1872^{*} \\
450.0797 \\
2782.1570 \\
5912.6680 \\
-4895.5830 \\
-367.3847 \\
\end{array}$ & $\begin{array}{c}4.29 \\
1.34 \\
-1.78 \\
0.51 \\
0.56 \\
0.83 \\
-0.56 \\
-0.41\end{array}$ & $\begin{array}{c}485,746.6000^{* * *} \\
71,871.8900^{* * *} \\
-3459.9430 \\
-4070.5140 \\
-133,559.3000 \\
-159,203.1000^{*} \\
107,510.8000 \\
-380.2064 \\
\end{array}$ & $\begin{array}{c}9.18 \\
2.90 \\
-0.82 \\
-0.36 \\
-1.39 \\
-1.83 \\
1.00 \\
-0.04\end{array}$ \\
\hline $\begin{array}{c}\text { Institutions and services } \\
\text { Distance to extension office } \\
\text { Distance to market } \\
\text { Extension contact } \\
\text { Training received } \\
\text { Agricultural credit } \\
\end{array}$ & $\begin{array}{c}-949.9591 \\
1535.0190^{* * *} \\
-42,417.2700^{* *} \\
-25,641.4400 \\
-1.3921^{* *}\end{array}$ & $\begin{array}{l}-0.30 \\
2.44 \\
-2.24 \\
-0.81 \\
-2.15\end{array}$ & $\begin{array}{c}3161.3470^{* * *} \\
-581.4647^{* * *} \\
6926.1370 \\
18,432.2600^{*} \\
-0.1130 \\
\end{array}$ & $\begin{array}{c}2.84 \\
-2.67 \\
1.05 \\
1.80 \\
-0.98 \\
\end{array}$ & $\begin{array}{c}13,858.3800 \\
-656.4904 \\
-103,180.3000 \\
-164,965.5000 \\
2.8045^{* *} \\
\end{array}$ & $\begin{array}{l}1.11 \\
-0.28 \\
-1.33 \\
-1.16 \\
2.38\end{array}$ \\
\hline $\begin{array}{l}\text { Modern technology } \\
\text { Fertilizer use }\end{array}$ & $10,182.4300$ & 0.46 & 297.2352 & 0.04 & $55,898.1300$ & 0.60 \\
\hline $\begin{array}{l}\text { Revealed motive } \\
\text { High yield } \\
\text { Ready market }\end{array}$ & $\begin{array}{c}94,111.9300 * * \\
12,668.5700\end{array}$ & $\begin{array}{l}2.23 \\
0.41\end{array}$ & $\begin{array}{c}109,928.0000 * * * \\
-8651.7660\end{array}$ & $\begin{array}{c}7.05 \\
-0.80\end{array}$ & $\begin{array}{c}-694,756.4000^{* * *} \\
276,635.5000^{*}\end{array}$ & $\begin{array}{l}-3.89 \\
1.82\end{array}$ \\
\hline $\begin{array}{c}\text { Location } \\
\text { Ebonyi state } \S\end{array}$ & $33,849.8700 * * *$ & 3.37 & $16,790.9600^{* * *}$ & 4.74 & $-89,978.7200^{* *}$ & -2.16 \\
\hline $\begin{array}{l}\text { Model diagnostics } \\
\text { Log likelihood } \\
\text { Wald } \chi^{2}(60 \mathrm{df}) \\
\end{array}$ & $\begin{array}{c}-10,602.411 \\
741.98^{* * *}\end{array}$ & & & & & \\
\hline $\begin{array}{r}\text { Correlation between the error terms } \\
\rho_{\text {(yam, cassva })} \\
\rho_{(\text {yam }, \text { rice })} \\
\rho_{\text {(cassava, rice })} \\
\text { Wald } \chi_{(3 \mathrm{df})}^{2}\left(\mathrm{H}_{0}: \text { Correlation }\right. \\
\text { between pairs of disturbance terms } \\
\text { are jointly } 0) \\
\text { Number of observations }\end{array}$ & $\begin{array}{c}0.1257^{* *} \\
0.0335 \\
-0.4134^{* * *} \\
32.2041^{* * *} \\
400\end{array}$ & $\begin{array}{c}2.30 \\
0.48 \\
-7.63\end{array}$ & & & & \\
\hline
\end{tabular}


In the empirical model, we have used relative prices of key inputs (i.e., fertilizers, labor and plow), which are normalized by respective output prices in each model. The reason for doing this is two-fold. First, it is assumed that the shift in the relative prices of major inputs will induce farmers to diversify their crop portfolio. Second, since the ratio is unit free, we have avoided collinearity that may arise from specifying close substitutes (e.g., cassava and yam) in the models.

Since, parameters of the multivariate Tobit model cannot directly reveal the magnitude of the effect, we compute elasticities and present them in Table 4, which show responsiveness of a $1 \%$ change in the relevant variable on the probability of producing each food crop and its corresponding profitability except for the dummy variables where it measures the responsiveness of a discrete change from zero to unity. It is clear from Table 4 that various factors exert differential impacts on the choice of individual food crops vis-à-vis profitability. A rise in the relative wage of labor will significantly increase the probability of producing yam and its profitability. The elasticity value indicates that a $1 \%$ rise in the relative price of labor wage will increase the probability of producing yam and its profitability by $2.9 \%$. The main reason may be due to the fact that the farmers of the study area exclusively sold most of their yam crop [11]. Therefore, when labor wage rises, farmers use labor in yam production because the increased labor cost can be offset from the sale of the crop that has a higher selling price and profitability than cassava (Table 2). On the other hand, a rise in the relative price of inorganic fertilizer will induce farmers to produce rice although the level of impact is small. Again, rice is also destined for the market and $68 \%$ of the rice producers applied fertilizers but at a rate much lower than the recommended level [11]. Therefore, when fertilizer price increases, farmers tend to apply fertilizers in rice because the increased fertilizer cost can be offset by higher yields and/or higher returns because rice price and profitability is highest (Table 2). However, Rahman [30] noted that a rise in fertilizer price significantly reduces crop diversity on farms in Bangladesh. A rise in the relative price of plowing will significantly reduce the probability of producing yam as well as rice and their profitability. This is because a minimum amount of plowing is necessary to ensure that the soils are sufficiently loosened for optimum crop growth. Therefore, farmers cannot adjust the rising cost of plowing by reducing its use and therefore, the rising effect significantly reduces the probability of producing yam and rice and profits generated therefrom. Rahman [30] also noted that a rise in animal power price, which is used for plowing, significantly reduces crop diversity on farms in Bangladesh. Table 2 clearly shows that plowing cost per ha is highest for rice followed by yam which complements the findings.

Among the socio-economic factors, farm size seems to be the most dominant factor that significantly increases the probability of choosing all three crops and profits generated therefrom. However, the marginal impact of farm size is substantially higher in raising profitability of rice. The elasticity value indicates that a $1 \%$ increase in farm size will increase profits from rice production by $1.2 \%$, which is substantial. Table 1 clearly showed that rice production fetches highest level of profit per ha. Both Rahman [30] and Benin et al. [27] noted significantly positive influence of farm size on crop diversity on farms in Bangladesh and Ethiopia, respectively. Family size significantly influences rice production. Benin et al. [27] also noted significantly positive influence of male members in the family on cereal crop diversity on farms in Ethiopia. It is interesting to find that those who choose to produce rice do not identify their main occupation as farmers. Table 2 shows that only $52 \%$ of the respondents identified farming as their main occupation, while the remaining $48 \%$ of the respondents identified non-farm activities (i.e., comprising of businesses, self-employment and salaried profession) as their main occupation. Rice production, which is destined for the market, is chosen by these secondary farmers for commercial purpose. Subsistence pressure, which is an index measure of food self-sufficiency of the household in their own perception, shows that lower subsistence pressure significantly increases the probability of choosing yam and profits generated therefrom, because the crop is for sale [11]. 
Table 4. Elasticity of factors influencing choice of crop diversity and profitability.

\begin{tabular}{|c|c|c|c|c|c|c|}
\hline \multirow{2}{*}{ Variables } & \multicolumn{2}{|l|}{ Yam } & \multicolumn{2}{|l|}{ Cassava } & \multicolumn{2}{|l|}{ Rice } \\
\hline & Coefficient & $t$-Ratio & Coefficient & $t$-Ratio & Coefficient & $t$-Ratio \\
\hline \multicolumn{7}{|l|}{ Prices } \\
\hline Relative price of fertilizer & -0.0323 & -1.31 & 0.0151 & 0.94 & $0.1931^{* * *}$ & 2.94 \\
\hline Relative labor wage & $2.8851^{* * *}$ & 11.37 & -0.1181 & -1.02 & 0.1292 & 1.38 \\
\hline Relative price of plowing & $-0.2628^{* * *}$ & -2.55 & 0.0333 & 0.83 & $-0.7712^{* * *}$ & -5.87 \\
\hline \multicolumn{7}{|l|}{$\begin{array}{l}\text { Socio-economics } \\
\text { characteristics }\end{array}$} \\
\hline Farm operation size & $0.1582 * * *$ & 2.48 & $0.1757^{* * *}$ & 4.29 & $1.2379 * * *$ & 9.18 \\
\hline Family size & 0.1025 & 1.06 & 0.0815 & 1.32 & $0.4328 * * *$ & 2.90 \\
\hline Farming experience & -0.0008 & -0.01 & $-0.0929^{*}$ & -1.76 & -0.1143 & -0.82 \\
\hline Education & -0.0409 & -0.48 & 0.0274 & 0.51 & -0.0373 & -0.36 \\
\hline Tenancy & -0.0156 & -0.84 & 0.0057 & 0.55 & -0.0171 & -1.39 \\
\hline Main occupation as farmer $\S$ & 0.0041 & 0.09 & 0.0237 & 0.83 & $-0.0968^{*}$ & -1.83 \\
\hline Gender $\S$ & -0.0502 & -0.59 & -0.0308 & -0.57 & 0.1174 & 1.00 \\
\hline Subsistence pressure & $-0.8501^{* * *}$ & -3.55 & -0.0724 & -0.47 & -0.0115 & -0.04 \\
\hline \multicolumn{7}{|l|}{ Institutions and services } \\
\hline Distance to extension office & -0.0147 & -0.30 & $0.0891 * * *$ & 2.85 & 0.0681 & 1.11 \\
\hline Distance to market & $0.0438^{* * *}$ & 2.42 & $-0.0302 * * *$ & -2.67 & -0.0087 & -0.28 \\
\hline Extension contact & $-0.0270 * *$ & -2.22 & 0.0080 & 1.05 & -0.0253 & -1.33 \\
\hline Training received & -0.0106 & -0.81 & $0.0139^{*}$ & 1.78 & -0.0011 & -1.16 \\
\hline Agricultural credit & $-0.0348^{* *}$ & -2.12 & -0.0052 & -0.99 & $0.0436^{* * *}$ & 2.38 \\
\hline \multicolumn{7}{|l|}{ Modern technology } \\
\hline Fertilizer use & 0.0205 & 0.46 & 0.0016 & 0.06 & 0.0395 & 0.60 \\
\hline \multicolumn{7}{|l|}{ Revealed motive } \\
\hline High yield & $0.3390^{* *}$ & 2.21 & $0.7189 * * *$ & 6.79 & $-0.0730 * * *$ & -3.89 \\
\hline Ready market & 0.0324 & 0.41 & -0.0393 & -0.78 & $0.2467^{*}$ & 1.82 \\
\hline \multicolumn{7}{|l|}{ Location } \\
\hline Ebonyi state $\S$ & $0.1866^{* * *}$ & 3.32 & $0.1680 * * *$ & 4.69 & $-0.1538 * *$ & -2.16 \\
\hline Number of observations & 400 & & & & & \\
\hline
\end{tabular}

Among the institutions and services, remoteness of extension services increases the probability of choosing cassava and its profitability. As mentioned earlier, cassava is mainly produced for consumption [11]. Therefore, farmers located in remote areas from extension infrastructure produce cassava. Rahman [26] did not find any influence of extension contact on crop diversity in Bangladesh. The proximity to market shows some interesting results. An increase in the distance to market increases the probability of choosing yam and its profitability. This needs to be explained with respect to the place of yam in Nigerian society. Yam is not only a staple but also used for religious and other cultural festivals. Therefore, if the market is located further away, farmers producing yam can still sell their produce at the farmgate fetching higher prices because of the unique place of yam in Nigerian society. On the other hand, probability of producing cassava and profits is higher for farmers located in close proximity to the markets. This is because, although most of the cassava is for consumption, if the farmers chose to sell the product, proximity to the market will facilitate selling. It is encouraging to see positive influence of training on cassava production. This is perhaps due to launching of Cassava Plus, Cassava Bread Development Fund and other specific programs in recent years in Nigeria [43]. Availability of agricultural credit significantly increases the probability of producing rice and its profitability but has an opposite effect on yam, although the level of impact is small for both. In fact, use of agricultural credit is highest for rice (estimated at 1847.4 Naira per ha) and lowest for yam production (1568.9 Naira per ha) respectively [11]. Use of fertilizers does not seem to have any influence on the choice of crops. This may be due to the fact that only $47 \%$ of the farmers applied fertilizers in their crops with an estimated use rate of $52.8 \mathrm{~kg}$ per ha [11].

Among the revealed motives, high yield motive is significantly positively associated with the choice of producing yam and cassava but not rice. This is expected because physical yield per ha is 
significantly higher for cassava and yam as both are bulky crops, whereas yield of rice is significantly lower [11]. It is the ready marketability of rice that induces farmers to produce rice and profit generate therefrom. This finding reinforces the fact that rice production is taken as a business by the farmers destined for the market fetching highest profitability.

Finally, location has significant influence on crop choices and profitability. Probability of choosing yam and cassava and profitability is significantly higher for farmers in Ebony state, whereas choice of rice and profitability is significantly higher in Anambra state, a relatively urbanized area. Benin et al. [27] noted that the location of farms in Tigray region (which is an urban area) is associated with significantly higher level of crop diversity. Similarly, Rahman [30] noted that crop diversity is significantly higher in Comilla region, a developed and urban area.

\section{Conclusions and Policy Implications}

The aim of this study was to jointly identify the determinants of crop diversity (i.e., rice, yam, and cassava) vis-à-vis profits generated therefrom by farmers in Southeastern Nigeria using a multivariate Tobit model. The model diagnostic revealed jointness in the decision-making process, which cannot be discerned from the univariate approach that is commonly used in the literature. This is because the decisions to produce multiple food crops are significantly correlated.

Results reveal that farmers grow multiple crops instead of any single crop as $68 \%$ of the surveyed farmers grew at least two food crops. But profitability is highest for rice monoculture followed by yam and rice combination, both of which are mainly destined for the market. Profitability is lowest for cassava monoculture, grown largely by the smallest farms, which largely explains the persistent level of poverty and struggle for raising subsistence by farmers in Nigeria.

A range of price and non-price factors significantly influence the decision to choose crops and profits generated therefrom with variable level of impacts. Among the prices, a rise in the relative price of plowing significantly reduces profitability of yam and rice. Among the socio-economic factors, farm size is the most dominant determinant of crop diversity vis-à-vis profitability. Higher family size and farmers whose main occupation is not farming are more likely to choose rice production. Among the institutions and services, remoteness of extension infrastructure, training, and proximity to markets significantly increase the probability of choosing cassava and its profitability. In contrast, distance to market, lack of extension contact and agricultural credit significantly increase the probability of choosing yam and its profitability. Availability of agricultural credit, however, significantly increases the probability of choosing rice and its profitability. High yield is the main motive for growing yam and cassava whereas ready market is the main motive for producing rice. Location does matter as probability of choosing yam and cassava and profitability generated therefrom is significantly higher in Ebonyi state, whereas it is Anambra state for choice of rice and its profitability.

The following policy implications can be derived from the results of this study. First, targeted investment in institutions and services will significantly increase crop diversity and profits generated therefrom in one way or the other. The main area of investments are market infrastructure and facilities in rural areas, training for farmers, and provision of agricultural credit through formal banking institutions and/or facilitating non-governmental development organizations (NGOs) targeted at the farming population. Next is to invest in land reform in order to increase or consolidate average farm operation size, as this is the most dominant factor in promoting crop diversity vis-à-vis profitability. Nigeria is a vast country with highly unequal land resource base. Therefore, an effective land reform measure could result in consolidation of average farm size of the small holders to an optimum size, which will also promote commercialization of agriculture, as the impact of farm size is highest for rice production which in turn fetches highest profitability. Finally, measures are needed to stabilize relative prices of inputs, particularly plowing price, as it has significant detrimental effect on crop diversity vis-à-vis profitability. This can be achieved by improving rental markets for plowing machines and/or investment in livestock sector, which can then be used for draft animal power as evident in Asian economies. 
Although these policy options are challenging, effective implementation of these measures will significantly increase adoption of modern agricultural technologies in major food crops and subsequently raise crop production and support agricultural growth in Nigeria.

Acknowledgments: The paper was extracted from the second author's PhD thesis completed at the School of Geography, Earth and Environmental Sciences, University of Plymouth, UK in 2015. The data required for this project were generously funded by the Seale-Hayne Educational Trust, UK. The authors gratefully acknowledge the comments of two anonymous reviewers and the editor for constructive and critical comments that have substantially improved this paper. All caveats remain with the authors.

Author Contributions: Sanzidur Rahman analyzed the data, fitted the model and wrote the article. Chidiebere D. Chima collected the data, recorded and processed the data into digital format (i.e., SPSS).

Conflicts of Interest: The authors declare no conflict of interest.

\section{References}

1. Liverpool-Tasie, L.S.; Kuku, O.; Ajibola, A. Nigeria Strategy Support Program; Working Paper No. 21; International Food Policy Research Institute: Washington, DC, USA, 2011.

2. Aigbokhan, B.E. Poverty, Growth and Inequality in Nigeria: A Case Study; African Economic Research Consortium (AERC) Research Paper 102; African Economic Research Consortium: Nairobi, Kenya, 2000.

3. Ehui, S.; Tsigas, M. The role of agriculture in Nigeria economic growth: A general equilibrium analysis. In Proceedings of the International Association of Agricultural Economics (IAAE) Conference, Beijing, China, 16-22 August 2009.

4. Ayoade, A.R.; Adeola, R.G. Constraints to domestic industrialization of cassava in Osun State Nigeria. Ozean J. Soc. Sci. 2009, 2, 1-5.

5. Knipscheer, H.; Ezedinma, C.; Kormawa, P.; Asumugha, G.; Mankinde, K.; Okechukwu, R.; Dixon, A. Opportunities in the Industrial Cassava Market in Nigeria; International Institute for Tropical Agriculture: Nairobi, Kenya, 2007.

6. Nweke, F. New Challenges in the Cassava Transformation in Nigeria and Ghana; International Food Policy Research Institute: Washington, DC, USA, 2004.

7. Asiedu, R.; Maroya, N. Yam Improvement for Income and Food Security in West Africa (YIIFSWA); International Institute for Tropical Agriculture (IITA), Project Brief: Kenya, 2012.

8. Erhabor, P.O.I.; Ojogho, O. Demand analysis for rice in Nigeria. J. Food Technol. 2011, 9, 66-74. [CrossRef]

9. Awerije, B.O.; Rahman, S. Exploring the potential and performance of maize production in Bangladesh. Int. J. Agric. Manag. 2014, 3, 99-106. [CrossRef]

10. Nkonya, E.; Pender, J.; Kato, E.; Omobowale, O.; Phillip, D.; Ehui, S. Enhancing Agricultural Productivity and Profitability in Nigeria. Nigeria Strategy Support Program; Brief \# 19; International Food Policy Research Institute: Washington, DC, USA, 2010.

11. Chima, C.D. Socio-Economic Determinants of Modern Agricultural Technology Adoption in Multiple Food Crops and Its Impact on Productivity and Food Availability at the Farm Level: A Case Study of South-Eastern Nigeria. Ph.D. Thesis, University of Plymouth UK, Plymouth, UK, 2015.

12. Manyong, V.M.; Ikpi, A.; Olayemi, J.K.; Yusuf, S.A.; Omonona, B.T.; Okoruwa, V.; Idachaba, F.S. Agriculture in Nigeria: Identifying Opportunities for Increased Commercialization and Investment. IITA Publication Series: Ibadan, Nigeria, 2005; p. 159.

13. Ajibefun, I.A. Cropping System. Technical efficiency and policy options: A Stochastic Frontier Analysis of Nigerian small-scale farmers. Q. J. Int. Agric. 2006, 45, 145-169.

14. Singh, S. Contract farming for agricultural diversification in the India Punjab: A study of performance and problems. Indian J. Agric. Econ. 2000, 56, 283-294.

15. Bamji, M.S. Diversification of agriculture for human nutrition. Curr. Sci. 2000, 78, 1-7.

16. Guvele, C.A. Gains from crop diversification in the Sudan Gezira scheme. Agric. Syst. 2001, 70, 319-333. [CrossRef]

17. Van den Berg, M.M.; Hengsdijk, H.; Wolf, J.; Ittersum, M.K.V.; Guanghuo, W.; Roetter, R.P. The impact of increasing farm size and mechanization on rural income and rice production in Zhejiang province, China. Agric. Syst. 2007, 94, 841-850. [CrossRef] 
18. Kar, G.; Singh, R.; Verma, H.N. Alternative cropping strategies for assured and efficient crop production in upland rain fed rice areas of Eastern India based on rainfall analysis. Agric. Water Manag. 2004, 67, 47-62. [CrossRef]

19. Rahman, S. Whether crop diversification is a desired strategy for agricultural growth in Bangladesh. Food Policy 2009, 34, 340-349. [CrossRef]

20. Llewelyn, R.V.; Williams, J.R. Nonparametric analysis of technical, pure technical, and scale efficiencies for food crop production in East java, Indonesia. Agric. Econ. 1996, 15, 113-126. [CrossRef]

21. Haji, J. Production efficiency of smallholders' vegetable-dominated mixed farming system in Eastern Ethiopia: a non-parametric approach. J. Afr. Econ. 2007, 16, 1-27. [CrossRef]

22. Coelli, T.J.; Fleming, E. Diversification economies and specialization efficiencies in a mixed food and coffee smallholder farming system in Papua New Guinea. Agric. Econ. 2004, 31, 229-239. [CrossRef]

23. Fawole, O.P.; Oladele, O.I. Sustainable food crop production through multiple cropping patterns among farmers in South Western Nigeria. J. Hum. Ecol. 2005, 21, 245-249.

24. Mariano, M.J.; Villano, R.; Fleming, E. Factors influencing farmers' adoption of modern rice technologies and good management practices in the Philippines. Agric. Syst. 2012, 110, 41-53. [CrossRef]

25. Uaiene, R.N.; Arndt, C.; Masters, W.A. Determinants of Agricultural Technology Adoption in Mozambique; Discussion Papers No. 67E; National Directorate of Studies and Policy Analysis, Ministry of Planning and Development: Maputo, Mozambique, 2009.

26. Rahman, S. Determinants of crop choices by Bangladeshi farmers: A Bivariate Probit analysis. Asian J. Agric. Dev. 2008, 5, 29-42.

27. Benin, S.; Smale, M.; Pender, M.J.; Gebremedhin, B.; Ehui, S. The economic determinants of cereal crop diversity on farms in the Ethiopian Highlands. Agric. Econ. 2004, 31, 197-208. [CrossRef]

28. Floyd, C.; Harding, A.-H.; Paudel, K.C.; Rasali, D.P.; Subedi, K.; Subedi, P.P. Household adoption and the associated impact of multiple agricultural technologies in the western hills of Nepal. Agric. Syst. 2003, 76, 715-738. [CrossRef]

29. Willock, J.; McGregor, M.M.; Sutherland, A.; Edwards-Jones, G.; Morgan, O.; Dent, B.; Grieve, R.; Gibson, G.; Austin, E. Farmers' attitudes, objectives, behaviors, and personality traits: The Edinburgh study of decision making on farms. J. Vocat. Behav. 1999, 54, 5-36. [CrossRef]

30. Rahman, S. The economic determinants of crop diversity on farms in rural Bangladesh. J. Int. Agric. Trade Dev. 2009, 5, 51-70.

31. McDonald, J.F.; Moffit, R.A. The uses of tobit analysis. Rev. Econ. Stat. 1980, 61, 318-321. [CrossRef]

32. Lansink, A.O.; van den Berg, M.; Huirne, R. Analysis of strategic planning of Dutch pig farmers using a multivariate probit model. Agric. Syst. 2003, 78, 73-84. [CrossRef]

33. Teklewold, H.; Kassie, M.; Shiferaw, B. Adoption of multiple sustainable agricultural practices in rural Ethiopia. J. Agric. Econ. 2013, 64, 597-623. [CrossRef]

34. Rahman, S.; Akter, S. Determinants of livelihood choices: An empirical analysis from rural Bangladesh. J. South Asian Dev. 2014, 9, 287-308. [CrossRef]

35. Barslund, M.C. MVTOBIT: Stata Module to Calculate Multivariate Tobit Models by Simulated Maximum Likelihood (SML). 2007. Statistical Software Components S456875, Boston College Department of Economics, revised 13 October 2009, Available online: http://ideas.repec.org/f/pba424.html (accessed on 25 March 2013).

36. Ebonyi State Agricultural Policy. Ebonyi State Government Plan and Policy Thrust Document; A Policy Document of Ebonyi State Government: Enugu, Nigeria, 2010.

37. National Population Commission. Official Population Figure of Ebonyi State Nigeria; NPC: Abuja, Nigeria, 2006.

38. Arkin, H.; Colton, R.R. Tables for Statisticians, 2nd ed.; Harper and Row Publishers: New York, NY, USA, 1963.

39. Beedell, J.; Rehman, T. Using social-psychology models to understand farmers' conservation behaviour. J. Rural Stud. 2000, 16, 117-127. [CrossRef]

40. Kobrich, C.; Rehman, T.; Khan, M. Typification of farming systems for constructing representative farm models: two illustrations of the application of multi-variate analyses in Chile and Pakistan. Agric. Syst. 2003, 76, 141-157. [CrossRef]

41. Sanginga, N. Roots and tuber crops (Cassava, yam, potato and sweet potato). In Proceedings of the An Action Plan for African Agricultural Transformation Conference, Dakar, Senegal, 21-23 October 2015. 
42. Rahman, S.; Chima, C.D. Determinants of modern technology adoption in multiple food crops in Nigeria: A multivariate probit approach. Int. J. Agric. Manag. 2014, 4, 100-109.

43. Natsa, R.T. Nigeria: Harnessing the Potential in Cassava, July 25, 2013. Available online: http:/ / allafrica.com/stories/201307250475.html (accessed on 8 November 2014).

(C) 2016 by the authors; licensee MDPI, Basel, Switzerland. This article is an open access article distributed under the terms and conditions of the Creative Commons by Attribution (CC-BY) license (http:/ / creativecommons.org/licenses/by/4.0/). 